\title{
HLA Class I Panel Reactive Antibody Measurement
}

National Cancer Institute

\section{Source}

National Cancer Institute. HLA Class I Panel Reactive Antibody Measurement. NCI

Thesaurus. Code C128967.

The determination of the amount of human leukocyte antigen (HLA) class I panel reactive antibody present in a sample. 